\title{
ESRRB Gene
}

National Cancer Institute

\section{Source}

National Cancer Institute. ESRRB Gene. NCI Thesaurus. Code C139917.

This gene plays a role in transcriptional regulation of genes that regulate the

maintainance of self-renewal and pluripotency of embryonic and trophoblast stem cells. 